\title{
Protectoral action of molsidomin ATP combination in chronic stress in young and old rats
}

\author{
L. P. Kuprash, T. M. Panteleymonova, L. B. Sharabura, I. F. Labunets, N. V. Sykalo, \\ V. V. Olar \\ State Institution “D. F. Chebotarev Institute of Gerontology NAMS of Ukraine”, Kyiv, Ukraine
}

Correspondence: panteleymonov01@ukr.net

Received: 07.09.2020; Accepted: 25.09.2020; Published: 15.10.2020

\begin{abstract}
Adaptive reactions to chronic stress, reaching a certain intensity, can become harmful and be involved in any pathological process. Therefore, the search for new ways to increase the adaptive capacity reduced with age and the body's resistance to the negative effects of chronic stress remains relevant.

The aim of the study was to experimentally study the age-related protective properties of the combination of molsidomine and ATP in chronic mild stress.

The experiments were performed on young (6 months) and old (26 months) Wistar rats exposed to stressors that changed periodically at random for 8 weeks. During the 6-8th week of the experiment, against the background of stress, the animals were sublingually administered a pharmacological combination based on molsidomine - $2 \mathrm{mg} / \mathrm{kg}$, ATP - $10 \mathrm{mg} / \mathrm{kg}$.

It was found that the adaptive reactions of young and old animals to chronic stress have qualitative and quantitative differences. Chronic stress in old rats caused changes in behavior and psycho-emotional state, deterioration of cognitive function, changes in lipoperoxidation. On the part of the immune system in old rats, against the background of a pronounced age involution of lymphoid organs, no significant changes in thymus mass and cellularity were observed during chronic stress, while the mass and cellularity of the spleen increased. The combination of molsidomine and ATP prevented post-stress changes in animal behavior, reduced anxiety, normalized social activity, restored the lost ability to recognize, improved cognitive function. The drug contributed to the preservation of the function of immunocompetent organs in young animals and to a lesser extent showed a protective effect in older animals against the background of involutional changes caused by both aging and chronic stress. The combination of molsidomine and ATP had an antioxidant effect.

Thus, in chronic mild stress, older animals showed a different response from young animals to both stress and the administration of molsidomine with ATP. The applied pharmacological combination can be considered as a promising stress-protective agent that has a complex effect on various pathogenetic links of chronic stress due to its neuro- and immunomodulatory, energy-saving, antioxidant properties.
\end{abstract}

Keywords: aging, chronic stress, anxiety, social activity, cellularity of the thymus and spleen, lipid peroxidation, combination of molsidomine and ATP, pharmacological action.

The problem of finding new ways to deal with the effects of stress is relevant, as modern life situations are increasingly leading to a sharp increase in psychological stress and pathogenic effects on human health. The effects of stress are determined not only by the type and strength of the stimulus, but also by the reactivity of the body at the time of stress, which depends on a number of factors, among which age plays a significant role [1-3]. According to one definition, "aging is a progressive loss of the ability to cope 
with stress, the inability to mobilize " means of protection" in response to the problem, both at the cellular level and at the body level" [2]. Today, the main mechanisms of stress are known and are reduced to the launch of a chain of integrated reactions caused by the activation of the hypothalamic-pituitaryadrenocortical axis and sympathoadrenal system of the body, resulting in increased release of glucocorticoids and catecholamines - major stress hormones that help mobilize the functions of organs and tissues responsible for adaptation [1,2]. Resistance of various organs and systems to stressors depends on the activity of stress-limiting systems, both central (GABA-ergic, opioidergic, etc.) and local (systems of prostaglandins, adenosine, free radical oxidation, nitric oxide generation), inhibiting the release of catecholamines, limiting excessive stress response and its damaging effect [4-6]. With aging, almost all stress-limiting systems undergo changes that affect resistance to stress-induced damage. Thus, due to age-related heterogeneous changes in neurotransmitter metabolism, the ratio of nervous and humoral factors is violated when a stress reaction is triggered, the adaptive component of stress is reduced, there is an inadequate reaction of the old body to stress [1]. In response to stress, the feedback mechanism does not work and hormones are produced even when they are high in the blood, as well as in the absence of stress, or in the recovery period after the end of the stress factor. One of the causes of dysregulation in aging is degenerative changes in the brain, in particular, dysfunction of hippocampal neurons, resulting in loss of control over the production of glucocorticoids in the adrenal glands, the excess of which damages neurons [3,7], leads to changes in psychophysiological response to stress. $[8,9$, 10].

As we age, local stress-limiting systems undergo changes, which affect stress resistance and can lead to a rapid failure of adaptation. Catecholamines and glucocorticoids alter the functioning of lipiddependent enzymes, receptors, ion penetration channels, lead to a decrease in energy reserves, activation of free radical processes, reduce resistance to hypoxia and ischemia, which ultimately causes the development of pathology $[2,11]$. One of the important mechanisms that induces changes in chronic stress at the cellular level is associated with mitochondrial dysfunction, including energy production, maintenance of membrane potential, and ionic homeostasis of cells, which deteriorate in the early stages of stress. It is shown that chronic stress is accompanied by a periodic decrease in the activity of the ATPase system ( $\mathrm{Mg}^{+2}$-ATPase), which depends on the formation of macroergic compounds in the organs [12]. The imbalance of energy needs and capabilities in chronic stress creates secondary hypoxia, which results in a violation of the synthesis of mediators, enzymes, cytosolic receptors of hormones, which deepens the functional disorders of various body systems [12]. With aging, energy production processes are also complicated by age-related hypoxia caused by heart and respiratory failure. This slows down the Krebs cycle, activates anaerobic glycolysis and energy deficiency, to which the brain is particularly sensitive, as a tissue with high metabolic activity, which depends on the processes of oxidative phosphorylation. The consequence of the energy deficit is a lack of recovered equivalents and a shift of balance in prooxidant-antioxidant system towards prooxidant processes $[8,13,14]$. It is shown that in chronic stress, as well as in aging, against the background of destructive disorders of the mitochondria of the brain (swelling, destruction of the sacrum, violation of the processes of division) there is an additional depletion of the antioxidant system [13].

No less important endogenous system, which is activated by the action of various stressors on the body, is the NO-ergic system. The regulatory role of nitric oxide is insufficiently studied, but it is known that as a neurotransmitter in the CNS, it is able to modulate the release of excitatory and inhibitory neurotransmitters [15], influence various motivational behaviors and play a fundamental role in neuroendocrine functions $[16,17,18]$.

Chronic stress provokes the development of not only neuroendocrine but also immune changes due to the presence of corticosteroid hormone receptors in immunocytes, the level of which increases sharply under stress, as well as as a result of stress-associated modulation of autonomic innervation of lymphoid organs $[19,20]$. Stress can affect immune function at the cellular level (phagocytosis, antibody production, cytotoxicity) and / or through leukocyte redistribution, which may increase or decrease the number of individual cell populations in different compartments of the immune system. Under the action of weak stressors and a moderate increase in glucocorticoids, the immune system is stimulated, while chronic stress suppresses the immune system by reducing the number and function of immune cells and enhancing immunosuppressive mechanisms, pro-inflammatory reactions, etc. [20]. That is, in chronic 
stress, as in aging, there are involutive processes in the lymphoid organs and suppression of immunity in general $[21,22,23]$. There is a decrease in the number of T- and B-lymphocytes, devastation of cell depots and the entry into the bloodstream of immature forms of immune cells, which can not fully respond to constant stress pressure and respond adequately to hormonal regulation [24]. Destroying the immune system, chronic stress makes the body more vulnerable to any internal and external influences and these processes deepen with age.

Thus, decrease in the reliability of biological systems and weakening of compensatory processes in aging limit adaptation to stressors, increase the body's vulnerability, increase the likelihood of pathological processes. Therefore, solving the problem of increasing the resistance of the old body to the damaging effects of stress remains an urgent need of modern medicine. Given the polysystemic nature and multifaceted pathogenetic mechanisms of stress disorders, it is advisable to use drugs with a wide range of pharmacological action. The effectiveness of a combination of drugs from different pharmacological groups, such as antipsychotics, antidepressants and anxiolytics with immunocorrectors or antioxidants, has been shown to increase the effectiveness of treatment and reduce the frequency of side effects of standard pharmacotherapy [25, 26]. Of interest in this regard is the fixed pharmacological combination of the donor nitric oxide molsidomine and ATP-LONG (ATP in the form of a coordination compound whose molecule includes adenosine-5-triphosphate, histidine, magnesium and potassium ions).

The aim of the study was to experimentally study the age characteristics of the protective effect of the combination of molsidomine and ATP in chronic mild stress in young and old animals.

\section{Material and methods}

The studies were performed on male Wistar rats, young (7 months) and old (26 months), obtained from the experimental biological clinic of the State Institution "D. F. Chebotarev Institute of Gerontology NAMS of Ukraine". All procedures and animal manipulations were performed in accordance with approved standard operating procedures (SOPs). The work on animals was performed in accordance with the European Convention for the Protection of Vertebrate Animals Used in Experiments or for Other Scientific Purposes (Strasbourg, 1986) and guidelines [27, 28]. The experiments used the minimum allowable number of laboratory animals in accordance with the applied method of statistical processing of results. Experimental and control groups included 8 individuals each. Decapitation of animals took place under ether anesthesia.

Molsidomine and ATP-LONG substances used in doses $(2.0 \mathrm{mg} / \mathrm{kg}$ and $10.0 \mathrm{mg} / \mathrm{kg}$, respectively) calculated by the extrapolation factor from the doses for humans, were used for the study [29]. A suspension of the required concentration of the components of the drug was prepared in $1 \%$ aqueous solution of Tween- 80 and administered sublingually at a rate of $0.1 \mathrm{ml}$ per $100 \mathrm{~g}$ of body weight. The administration procedure was performed daily once a day, in the morning 2 hours before feeding the rats. In each age group, the animals were divided into 3 subgroups: 1 - intact, 2 - control (stress), 3 experimental (which on the background of stress received a combination of molsidomine and ATP during 6-8 weeks of the experiment).

Chronic mild (unpredictable) stress was modeled according to the method of Willner P. [30], adapted to the conditions of the experiment [31]. The essence of the method was that for 8 weeks the rats were exposed daily to a mild stressor, which was constantly changing in an unpredictable sequence for the animals. The series of actions was repeated cyclically with a 7-day interval of stimulus replacement. To create uncomfortable conditions, "inclined cage", "wet litter", "overcrowded cage", inversion of lighting, food and drinking deprivation, unpleasant odor were used. According to the overall assessment (increased psychomotor activity, development of anxiety-phobic reactions, maladaptation, changes in dopamine and serotonin content and turnover in the striatum), Wistar rats show a high sensitivity to this model of chronic mild stress [31]. After completion of the course of drug administration, the functional parameters of the CNS of animals were studied using the following methods: study of anxiety - in the "open field" and "dark / light" chamber [32]; assessment of zoosocial activity (communicativeness and recognition) - in the test "three cameras" [33], cognitive function - by the conditional reaction of passive avoidance (CRPA) [34]. After decapitation, the animals were dissected, the thymus and spleen were 
removed, and their absolute and relative masses were established as the ratio of organ mass to body weight as a percentage (mass index). The cellularity of lymphoid organs was determined, for which the spleen and thymus were homogenized in Hanks' solution, centrifuged, and cells were counted in Goryaev's chamber [35].

The content of peroxidation products - malonic dialdehyde (MDA) was determined by spectrophotometric method by reaction with thiobarbituric acid in hemolysates of erythrocytes [36] and in homogenates of the brain of animals [37]. The calculation of MDA concentrations was performed according to the described methods by the molar extinction coefficient $(\varepsilon=1.56 \cdot 105 \mathrm{~mol} / \mathrm{l})$.

Statistical processing of the results was performed using Student's T-test (data are presented as $(\mathrm{M}+$ $\mathrm{m})$ ), as well as using the nonparametric Wilcoxon-Mann-Whitney test for independent samples (data are presented as the median, lower and upper quartiles - Me(LQ; UQ). Differences at $\mathrm{P}<0.05$ were considered statistically significant [38].

\section{Results and their discussion}

Behavioral reactions, which are based on the orienting reflex - motor and orienting-research activity, together with indicators of autonomic activity and emotional reactivity of animals, are considered as integral indicators of the state of the whole organism and are registered in the "open field". The test results showed that the time of exit from the center of the field in intact old rats was significantly longer than in young animals - $(51.6+9.3)$ and $(20.1+7.6) \mathrm{s}$, respectively, which characterizes different types of behavior - passive ("hiding") in the old and active ("fight or flight") - in the young animals. Under the influence of stress in young rats there was a tendency to suppress horizontal motor activity, statistically decreased vertical motor activity (Fig. 1A, 1B) and increased the frequency of grooming - from $0.5(0 \ldots 2)$ in intact animals to $1.5(0 \ldots 3)$. ) in animals with stress, indicating increased anxiety and psychoemotional stress. Such behavioral changes are a typical response to stress [39] and are caused by a mediator imbalance, which some authors associate with the prevalence of vasoconstrictive amines (epinephrine, norepinephrine) in the deficiency of vasodilating amines (dopamine) and increased concentrations of histamine and serotonin, which play a significant role in behavioral disorders [40, 41, 42]. The changes in stress behavior detected in young rats returned to normal after administration of a combination of molsidomine and ATP.

In older animals under stress there was a reduction in the latency of the exit from the center of the field from $(51.6+9.3) \mathrm{s}$ in intact to $(2.0+0.2) \mathrm{s}$ in control ones, an increase in grooming frequency (respectively from $1(0 \ldots 3)$ to $3(0 \ldots 5)$, as well as a reduction by 2 times in the number of vertical positions (Fig. 1B), which indicates a change in behavior from "passive" to "active" and an increase in the anxiety component in the behavior of animals under stress. The slightly different nature of the response to stress in older rats compared to young ones is apparently due to different initial individual level of stress hormones, which affects the psychodynamic type of behavior, changing it from "passive" to "active" and vice versa [42]. 

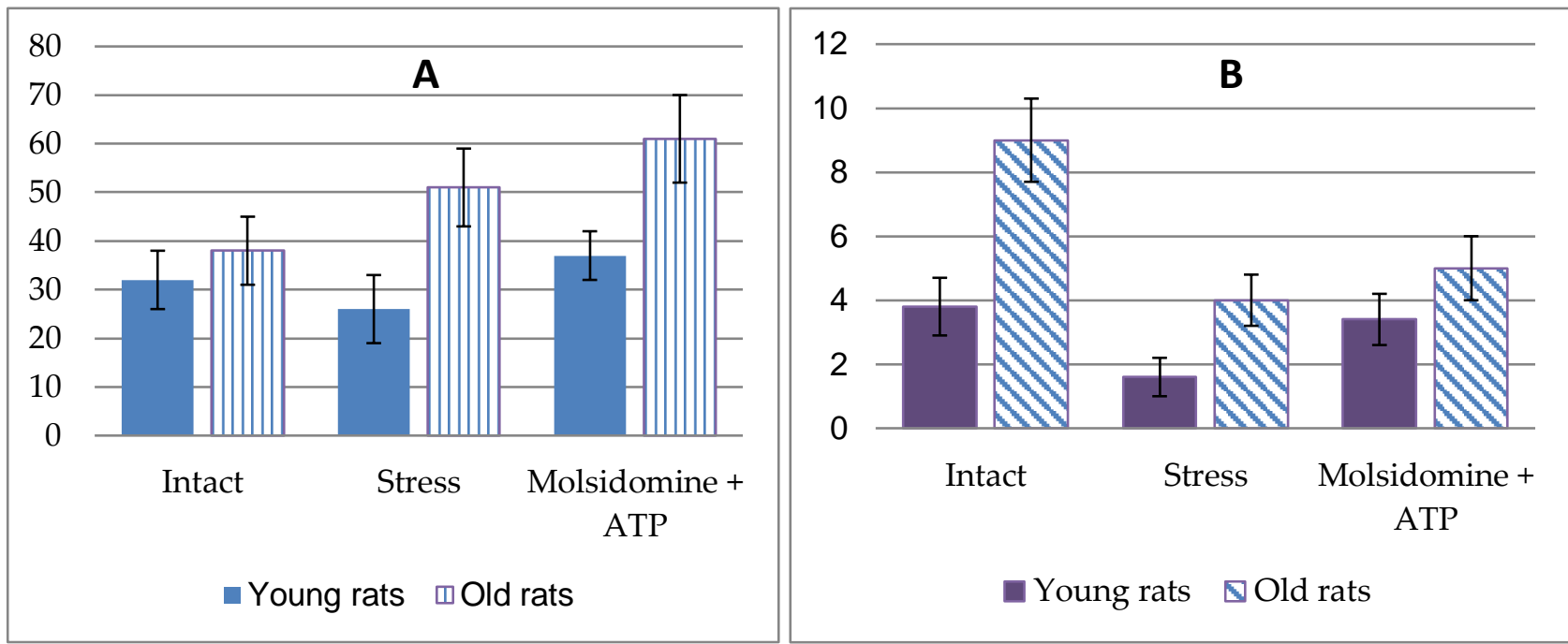

Figure 1. Horizontal (A) and vertical (B) motor activity of rats under stress and the introduction of molsidomine with ATP. On the $\mathrm{Y}$ axis - the number of crossed squares (A) and the number of vertical positions (B) in the open field $(\mathrm{M} \pm \mathrm{m})$.

After the introduction of the combination of molsidomine and ATP amid stress in old rats decreased anxiety, as evidenced by an increase in horizontal motor activity, maintaining vertical motor activity at the level of young intact animals (Fig. 1) and a reduction by 3 times in grooming frequency.

The anti-anxiety / anxiolytic effect of the studied combination was confirmed in the "dark / light chamber" test (Fig. 2).

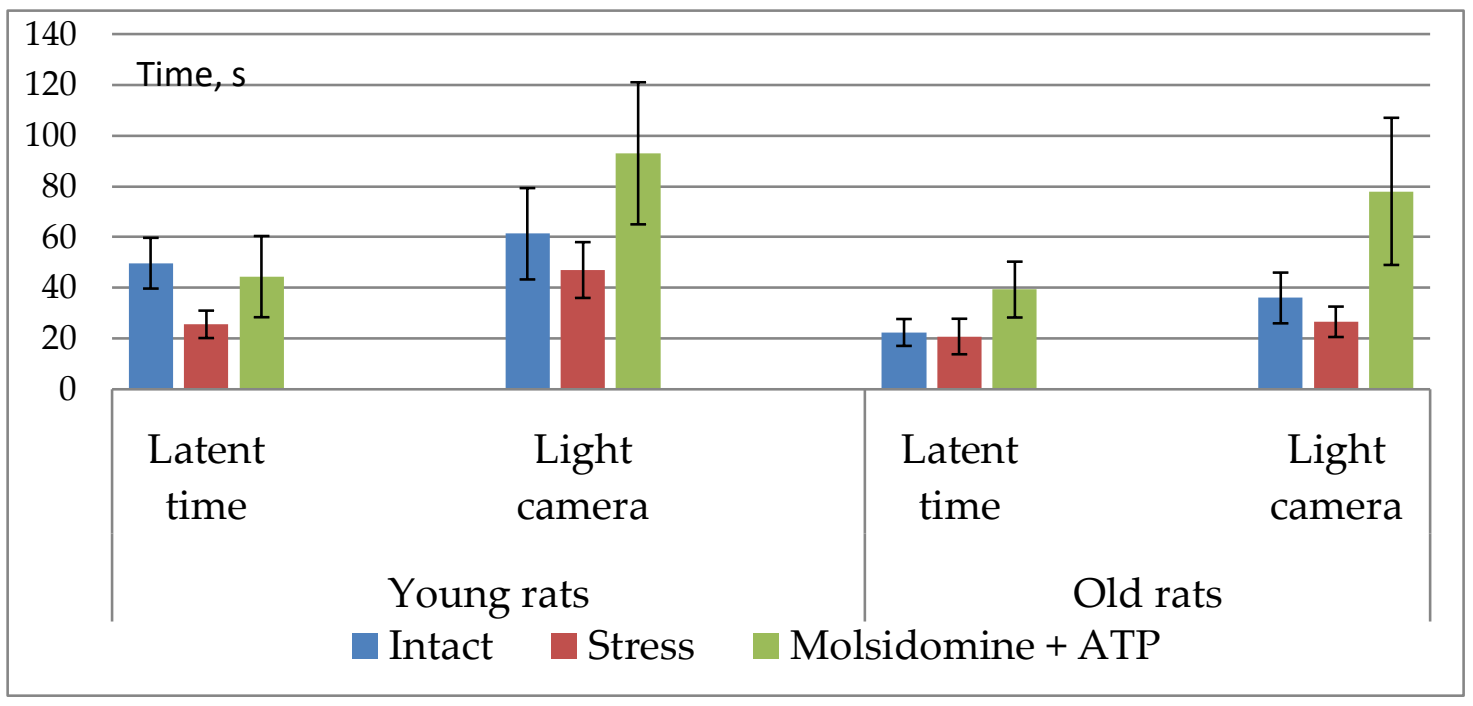

Figure 2. The latent time of entry into the dark chamber and the time spent in the light chamber in rats with stress under the influence of the combination of molsidomine and ATP $(\mathrm{M} \pm \mathrm{m})$.

It was found that old intact rats compared to young ones in the test conditions showed a shorter (by 2.3 times) latency period of the entry and a shorter (by 1.7 times) time spent in the light chamber, which is typical for animals with increased anxiety. Chronic stress had practically no effect on initially worsened performance in old rats, whereas in young animals it increased anxiety $=$ led to a reduction in latent time of entry into the dark chamber and the time spent in the light chamber. In this case, $100 \%$ of young and old animals in the control group went to the dark chamber. After the introduction of the combination of molsidomine and ATP in young rats, there was a positive dynamics compared to the control ones: the latency time of entering the dark chamber increased by 1.7 times and almost by 2 times 
- the time spent in the light chamber. In older rats, after administration of molsidomine with ATP, the latency time of entering the dark chamber and the time spent in the light chamber also increased by 2 and 1.5 times, respectively. In both age groups, $12.5 \%$ of the animals receiving the combination of molsidomine and ATP did not enter the dark chamber at all during the observation. Thus, the combination of molsidomine and ATP due to its anti-anxiety / anxiolytic action helped to increase the resistance of animals of both ages to stress.

Chronic stress worsened the social activity of animals, which was assessed by the indicators of the test "three chambers": communicativeness - by the number and duration of sensory contacts with an unfamiliar rat-stimulus (S1); recognition and giving preference to novelty - by the number and duration of contacts with the already familiar rat-stimulus (S1) and the new unfamiliar stimulus (S2).

It was found that in young animals with chronic stress, the time of sensory contact with the unfamiliar rat-stimulus S1 was reduced, while the number of contacts did not change. In older rats with initially reduced communicativeness, chronic stress even increased the number of contacts with the S1 stimulus, but their duration was very low (Fig. 3).
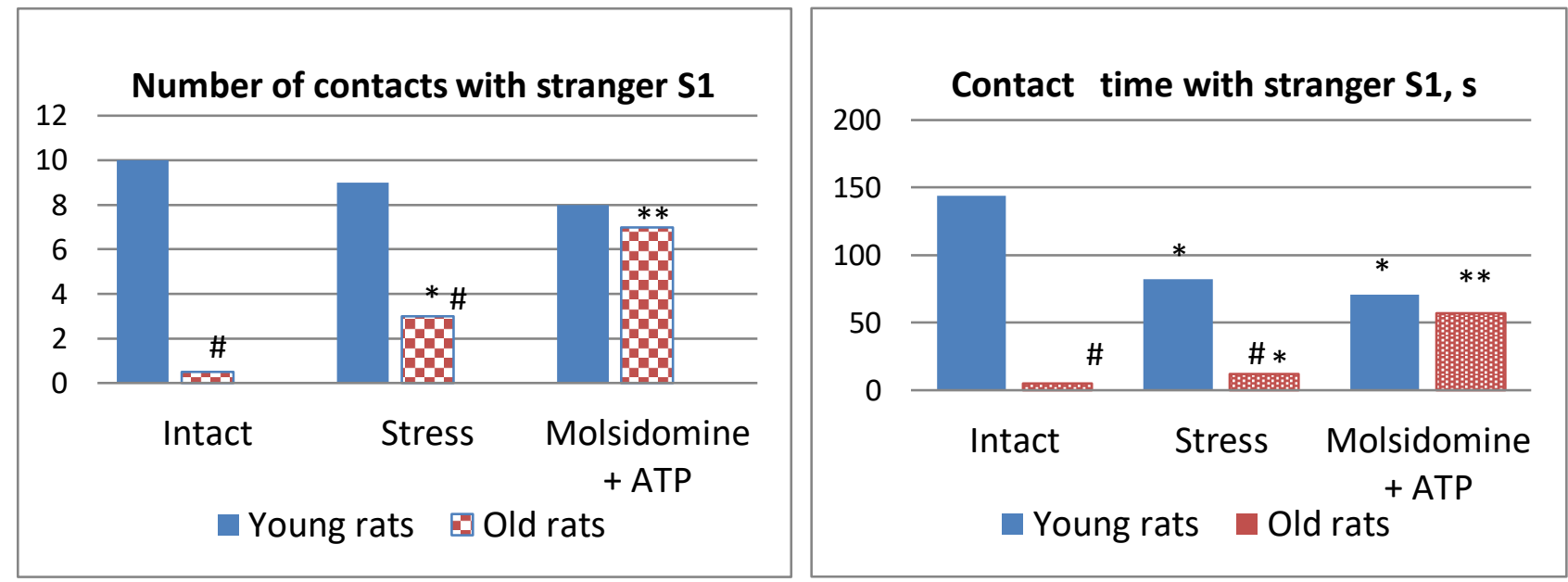

Figure 3. Indicators of communicativeness of rats under chronic stress and the administration of the combination of molsidomine and ATP.

Data are presented as median; P are calculated by the nonparametric Wilcoxon-Mann-Whitney U-test.

Notes: \# - $\mathrm{P}<0.05$ compared to young rats; ${ }^{*} \mathrm{P}<0.05$ compared to intact rats of the corresponding age; ** - $\mathrm{P}<0.05$ compared to control (stress) rats of the corresponding age.

The administration of the combination of molsidomine and ATP did not affect the indicators of communicativeness in stressed young rats, while in older animals there was a significant increase in the number and duration of contacts with an unfamiliar stimulus, while leveling the age differences.

In the test for recognition and giving preference to novelty in the choice between an already familiar (S1) and a new unfamiliar rat-stimulus (S2), young rats clearly preferred the new stimulus S2, while contact with the already familiar stimulus $\mathrm{S} 1$ in most animals was minimal or absent (Fig. 4). 


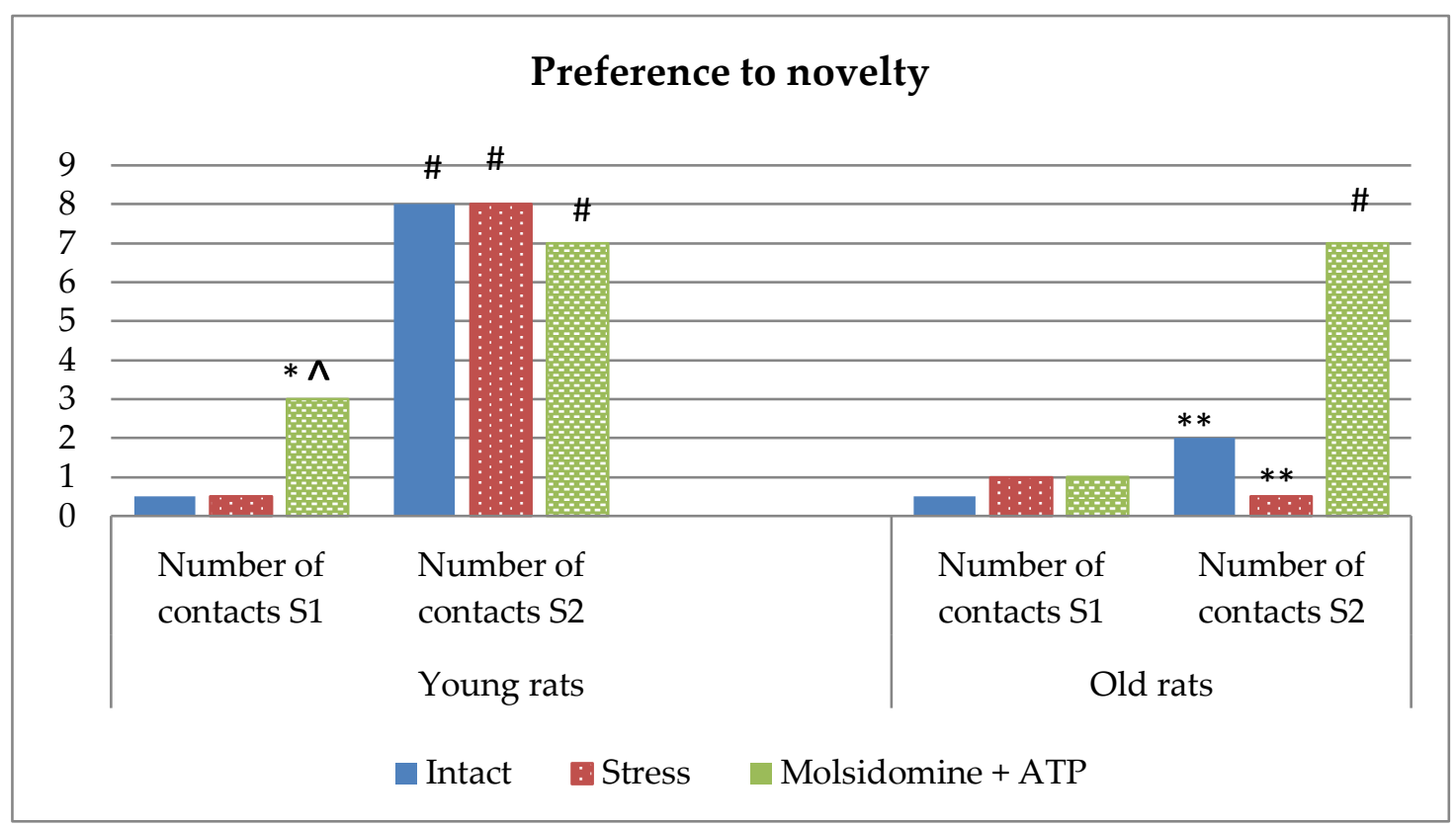

Figure 4. Indicators of recognition and giving preference to novelty - the number of contacts with the already familiar (S1) and new (S2) rat-stimulus in chronic stress and the administration of the combination of molsidomine and ATP. The data are presented as median;

$\mathrm{P}$ are calculated by nonparametric Wilcoxon-Mann-Whitney U-test.

Notes: \# - $\mathrm{P}<0.05$ when comparing S2 with $\mathrm{S} 1 ;^{\wedge}{ }^{\wedge} \mathrm{P}<0.05$ compared with intact rats; ${ }^{*}-\mathrm{P}<0.05$ compared with control (stress) rats of the corresponding age;** $-\mathrm{P}<0.05$ compared with young rats.

In contrast to young, in older intact rats, the number of contacts with the unfamiliar partner S2 was significantly lower (9.6 times) and did not differ statistically from the number of contacts with the already familiar stimulus S1, i.e. old animals did not distinguish new stimulus and did not prefer novelty. Chronic stress did not significantly affect recognition performance in young animals, whereas in older ones it led to a complete loss of recognition function, as evidenced by an even greater reduction in the number of contacts with the new S2 stimulus. Under the influence of the combination of molsidomine and ATP in old rats with a relatively low number of contacts with stimulus S1, their number significantly increased with stimulus S2, indicating the restoration of the ability to identify familiar and new partners and the normalization of distorted under the influence of stress zoo social behavior.

It is known that stress has the greatest effect on cognitive function due to the effect of the stress hormone corticosterone on synaptic plasticity. In our studies in the Passive Avoidance Conditional Response Test (PACR), only $66 \%$ of older animals with stress retained a memory trace, whereas in the young animals of the control group, as well as in young and old rats of the experimental groups receiving a combination of molsidomine and ATP, the proportion of animals with generated PACR was $100 \%$. That is, the combination of molsidomine and ATP prevented a decrease in cognitive function under stress in older rats.

Given the negative effects of chronic stress and immunosuppression that occur with age, it was important to assess the effect of the studied pharmacological combination on the condition of the lymphoid organs of animals. Analysis of the results showed that intact rats showed clear age differences in the mass and cellularity of the thymus: the relative mass of the thymus in older rats compared with young ones was reduced by 2.7 times $(\mathrm{P}<0.05)$, cellularity - by 2.4 times $(\mathrm{P}<0.05)$ (Fig. 5). 

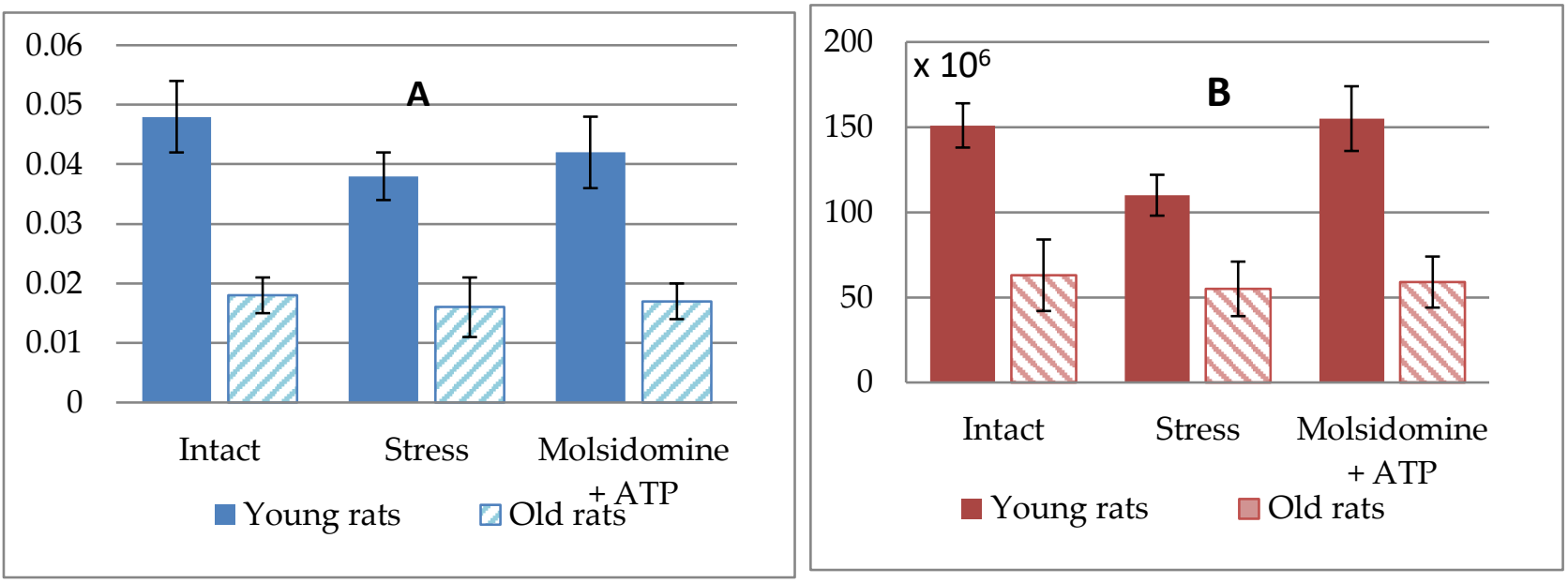

Figure 5. Relative mass (A) and cellularity (B) of the thymus of rats under stress and the introduction of a combination of molsidomine and ATP (ordinate axis: A - the ratio of organ mass to body weight (mass index), \%; B - the number of cells containing nuclei, $1 \times 10^{6}$ ).

In older rats with initially critically low thymus mass, there was no response to chronic mild stress - the organ mass and the content of cells containing nuclei did not change under stress or after administration of molsidomine with ATP. In contrast to older rats, young rats showed a typical response to chronic stress - a statistically significant decrease in thymus mass index and its cellularity, while the combination of molsidomine and ATP contributed to the normalization of both indicators.

Similar changes were observed in the spleen of rats. Thus, in intact old rats, relative mass was reduced compared to young rats (by $35 \%, \mathrm{P}<0.05$ ) and cellularity (by $38 \%, \mathrm{P}<0.05$ ) of the organ (Fig. 6).
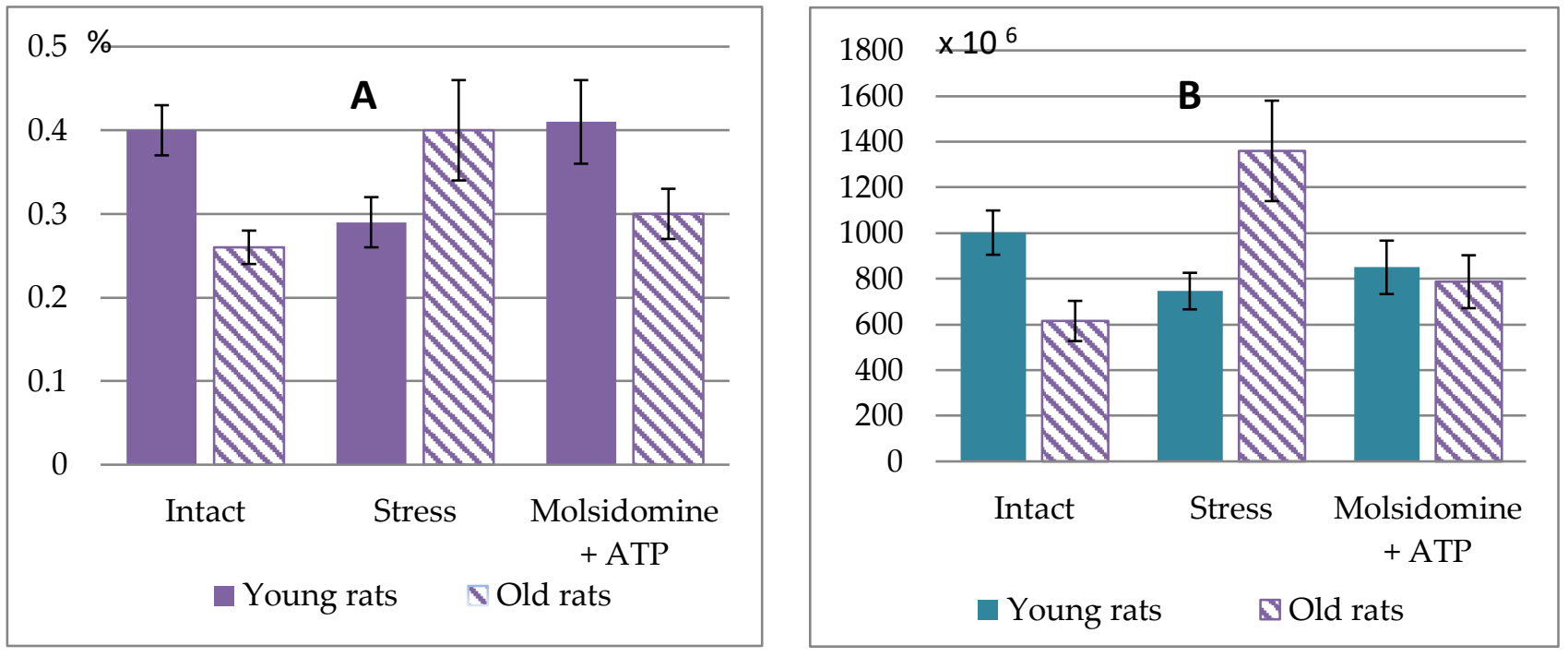

Figure 6. Relative mass (A) and cellularity (B) of the spleen of rats after chronic stress and the administration of the combination of molsidomine and ATP (on the y-axis: A - mass index, \%; B - the number of cells containing nuclei, $\left.1 \times 10^{6}\right)$.

Chronic stress in older rats caused a probable increase in both parameters, while in the group of animals receiving molsidomine with ATP, the indicators approached the level of intact animals. 
In young animals under the influence of chronic stress, the mass of the spleen and its cellularity decreased (by 28 and $24 \%$, respectively), which corresponds to the literature on the reduction of cellularity and hypoplasia of B- and T-zones of the spleen under chronic stress due to increased apoptotic cells and reduced transport of thymic immigrant cells to the spleen [43]. Administration of molsidomine with ATP to young rats with stress prevented organ weight loss but did not affect organ cellularity.

One of the local stress-limiting systems, which undergoes significant changes during aging, is a system of free radical oxidation $[8,14]$. With age, the number of LPS products increases and antioxidant activity decreases, of both enzymatic and non-enzymatic type, which negatively affects the resistance to stress, while the suppression of lipoperoxidation is associated with increased resistance to extreme factors. [44, 45] .

Determination of MDA in erythrocytes and brain of intact rats showed a statistically significant increase in MDA content, which corresponds to the literature (Fig. 7). Under stress in young rats, the change in MDA content in erythrocytes did not reach statistical values, while in the brain the indicator increased by $23 \%(\mathrm{P}<0.05)$ and returned to baseline under the influence of the combination of molsidomine and ATP. In older animals, with initially elevated MDA levels, the MDA content in erythrocytes also did not change under the influence of stress, while in the brain there was a significant decrease in the rate.
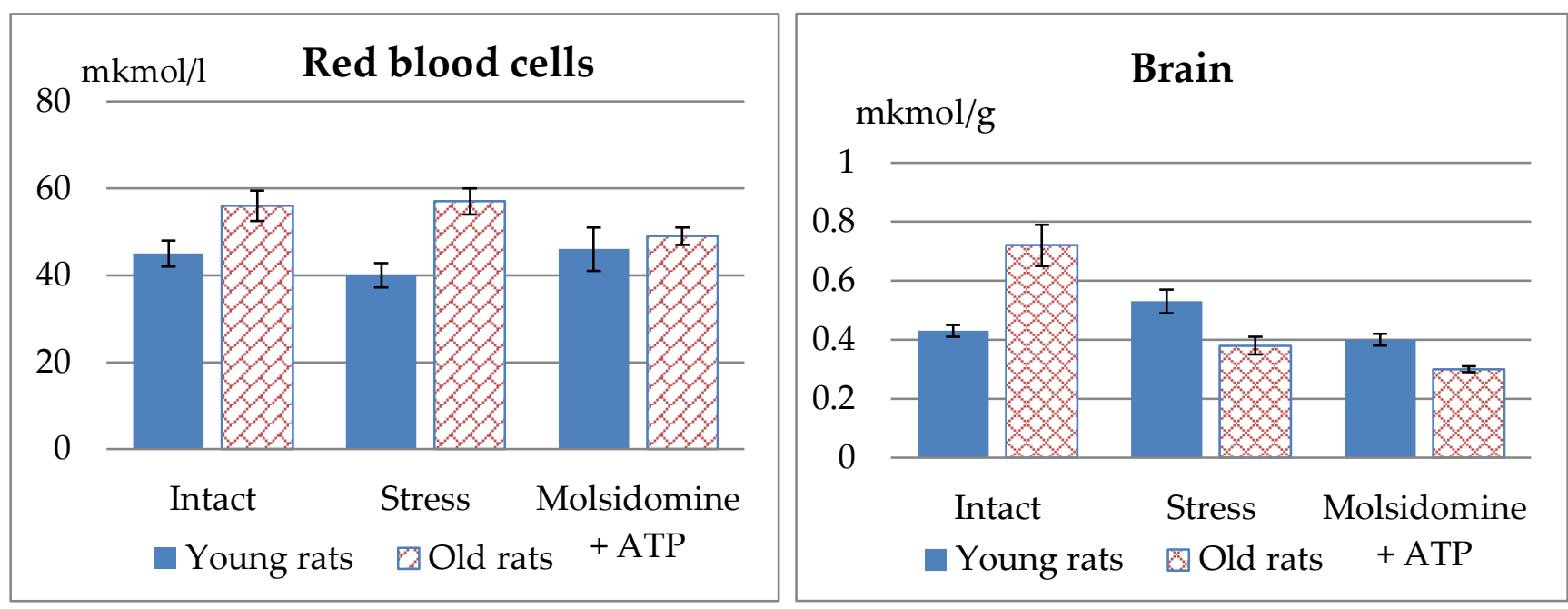

Figure 7. The content of MDA in erythrocytes and brain homogenate of rats under chronic stress and with the administration of the combination of molsidomine with ATP $(\mathrm{M} \pm \mathrm{m})$.

To explain this fact, it should be noted that according to the literature, in chronic stress, LP processes change depending on the stage of stress response - activation of LP occurs after previous inhibition, and low level of LP combined with high antioxidant activity corresponds to long-term adaptation [46]. That is, based on our data on the opposite change in the level of MDA in the brains of animals of different ages, we can assume that at a certain time young and old rats were at different stages of adaptation to stress, so the increase in peroxidation in the brains of old control animals may occur later than in the young ones. This may also be evidenced by elevated levels of MDA in the erythrocytes of old rats, where changes occur faster than in the brain. Although reduced levels of MDA indicate an increase in resistance to stress, the cost of such adaptation is too high, as it occurs due to depletion of the antioxidant system and structural disorders in the brain [46], which is especially important for the aging body. The introduction of molsidomine with ATP in old animals was accompanied by an even greater decrease in the content of MDA in the brain, which in this case did not help to eliminate the negative effects of chronic stress. However, for the final conclusion, research in this direction needs to be continued and expanded. 
Thus, the age characteristics of the response of animals to chronic mild stress and therapeutic and prophylactic administration of the combination of molsidomine and ATP were established. The mechanisms of stress-protective activity of the combined drug have yet to be studied, but it can be predicted that they are associated with the impact on the main stress-limiting systems of the body and with an indirect effect on energy supply, nitric oxide and antioxidant protection. The reasons for this assumption are the main directions of pharmacological action of the components of the combined drug ATP and molsidomine. Thus, ATP is not only a form of replenishment of the pool of macroergic phosphates, but also acts as a signaling substance that together with adenosine interacts with purinergic receptors in nerve, muscle, endothelial and other cells of the body. The extracellular participation of ATP in the regulation of neurotransmitter and neuromodulatory processes in the central and peripheral nervous systems, participation in the regulation of vascular, cardiac and pulmonary functions through specific purine receptors P1 and P2 has been established [47]. Another component of the combined agent is molsidomine, a nitric oxide donor that has vasodilating properties and reduces tissue oxygen demand, as well as causes neuroprotective and antioxidant effects [48, 49,50]. Nitric oxide limits the activation of the hypothalamic-pituitary-adrenal and sympathoadrenal systems and thus reduces the damaging effects of the stress response. As a rule, an increase in NO production is observed under the action of short-term or moderate stressors, and a decrease in its formation is manifested in the action of long-term stress factors [51]. Experimental data show that when the level of NO in the tissues decreases, the adaptive capacity of the body decreases and pathological changes in metabolism occur [52, 53]. It is shown that with the introduction of exogenous NO donors, the body's resistance to stress factors increases, while with the introduction of inhibitors of its synthesis, the body's endurance decreases [51, 54]. In the free state, the NO molecule has a short half-life (from 0.5 to $30 \mathrm{~s}$ ) and is rapidly destroyed. However, with excessive amounts in the cell, nitric oxide can bind to proteins and peptides, be deposited, migrate to the intercellular space and to cells of other organs and perform a signaling, protective or damaging effect there $[55,56]$. On the one hand, NO prevents membrane damage associated with excessive free radical generation and activation of lipid peroxidation, on the other hand, it is involved in the detoxification of superoxide with the formation of toxic peroxynitrite (ONOO-). That is, depending on specific conditions and concentrations, as well as the system of oxidative metabolism, nitric oxide can stimulate oxidation as a powerful prooxidant, and at the same time NO metabolites are involved in the mechanisms of endogenous antioxidant defense, which is proven for almost all cell types [54, 57]. Importantly, increasing the level of NO in cells, regardless of its source, effectively prevents a significant increase in its amount under stress by inhibiting the inducible form of the enzyme NO synthase (iNOS), localized in endothelial, epithelial, immune cells, smooth myocytes of the digestive organs, and is activated only by gene expression under the action of stress factors and some other mechanisms [54]. It is shown that in older animals under stress there is a decrease in the activity of enzymes of NO synthesis, reduction of its production and content in tissues, which contributes to the weakening of its antistress function and a decrease in the adaptive capacity of the body [58].

It is known that one of the first to respond to stress is the brain, in which vascular and nervous connections are disrupted, endothelium-dependent vasorelaxation of blood vessels deteriorates due to reduced bioavailability of nitric oxide. According to [59], already at the initial stage of chronic stress, the imbalance of the main vasoregulatory factors secreted by vascular endothelium (increased endothelin-1 production and decreased nitric oxide secretion) develops into endothelial imbalance with its negative consequences for cerebral hemodynamics. Decreased nitric oxide synthesis under prolonged stress disrupts the adhesive and aggregation properties of blood platelets and leukocytes [60, 61], potentiates coronary vasospasm, promotes ischemia and reduces resistance to stress [62, 63]. The condition of blood vessels also plays an important role for the immune system, as the process of migration of immune cells depends on the tone and permeability of blood vessels. On the part of the lymphoid organs under stress, even in young animals, involutional-sclerotic changes and hemodynamic disturbances are observed, which is also a consequence of endothelial dysfunction caused by the action of stress hormones [64]. In addition, with aging in the thymus increases the production of endothelin, which because of vasoconstrictor action impairs blood circulation, causing rapid degeneration of thymus tissue [65]. Thus, the normalization of the balance of endothelial mediators and inhibition of the synthesis of vasoconstriction factors can help eliminate the negative effects of chronic stress, and the system 
"endothelin - nitric oxide" may be one of those links, which is primarily aimed at the protective effect of our combined tool, including a donor of nitric oxide and ATP.

Thus, due to the complex effect on various pathogenetic links of chronic stress, the combination of molsildomine and ATP looks like a promising means of stress-protective action, in the implementation of which the leading role is played by neuro- and immunomodulatory, energy-saving, antioxidant properties.

We thank to the academician of the National Academy of Medical Sciences of Ukraine V.V. Bezrukov for the overall management of the project and the director of LLC "Pharmaceutical company" FarCos" M.Y. Shinkaryova for providing the substance of the drug for research.

Author Contributions: All authors participated equally in writing this commentary.

Conflicts of Interest: The authors declare no conflict of interest.

Information about Authors:

Liana P. Kuprash - DSc (Medicine), Head of the Geriatric Pharmacology Laboratory; https://orcid.org/0000-0001-8196-751X Tetyana M. Panteleymonova - PhD (Biology), Leading Researcher of the Geriatric Pharmacology Laboratory; https://orcid.org/00000002-3606-5805

Ludmila B. Sharabura - PhD (Biology), Leading Researcher of the Geriatric Pharmacology Laboratory; https://orcid.org/ 0000-0002-8182-7979

Irina F. Labunets - DSc (Medicine), Leading Researcher of the Pathophysiology and Immunology Laboratory

Nina V. Sykalo - PhD(Biology), Leading Researcher of the Laboratory of Physiology;

https://orcid.org/0000-0001-7812-8504

Vitaliy V. Olar - Junior Researcher of the Laboratory of Physiology; https://orcid.org/0000-0002-1298-2270 


\section{References}

1. Frolkis, V.V. Stress-vozrast-sindrom [Stress-age-syndrome (in Russian)]. Fiziol. Zh. 1991, 3, 3-10.

2. Sapolsky, R. Psikhologiya stressa [The psychology of stress. 3rd edition (in Russian)]. Peter: St. Petersburg, 2015; $\mathrm{p} 480$.

3. Fedorova, V.I.; Denisova, I.N. Stress i stareniye [Stress and aging (in Russian)]. Clinical gerontology 2013, 3-4, pp. 49-53.

4. Meerson, F.Z. Adaptatsionnaya meditsina : mekhanizmy i zashchitnyye effekty adaptatsii [Adaptation medicine: mechanisms and protective effects of adaptation (in Russian)]. Hypoxia med: Moscow, 1993; p 331

5. Pshennikova, M. G. Rol opioidnykh peptidov v reaktsii organizma na stress [The role of opioid peptides in the body's response to stress (in Russian)]. Pathological physiology and experimental therapy 1987, 3, pp. 85-90.

6. Pshennikova, M.G. Katekholaminy, oksid azota i ustoychivost' $\mathrm{k}$ stressornym povrezhdeniyam: vliyaniye adaptatsii $\mathrm{k}$ gipoksii [Catecholamines, nitric oxide and resistance to stress damage: the effect of adaptation to hypoxia (in Russian)]. Russian Journal of Physiology 2002, 4, pp. 485 - 495.

7. Goldstein, D.S.; Kopin, I.J.; Sharabi, Y. Catecholamine autotoxicity. Implications for pharmacology and therapeutics of Parkinson disease and related disorders. Pharmacol. Ther. 2014, 144, 3, pp. 268 82. doi: 10.1016/j.pharmthera.2014.06.006

8. Meshchaninov, V.N.; Shcherbakov, D.L.; Lukash, V.A. Metabolizm kletochnykh struktur pri starenii i stresse [Metabolism of cellular structures during aging and stress (in Russian)]. FSBI HРБ «USMU» MOH Russia. UGMU Publishing House: Yekaterinburg, 2017; p 308.

9. Carrasco, G.A. ; Van de Kar, L.D. Neuroendocrine pharmacology of stress . Euro. J. harm. 2003, 463, pp. 235-272. doi: 10.1016/s0014-2999(03)01285-8

10. Bremner, J.D. Traumatic stress: effects on the brain. Dialogues in clinical neuroscience 2006, 8, 4, pp. 2834.

11. Kishkun, A.A. Biologicheskiy vozrast i stareniye: vozmozhnosti opredeleniya i puti korrektsii [Biological age and aging: possibilities of definition and ways of correction (in Russian)]. GEOTAR-Media: Moscow, 2008; $\mathrm{p}$ 973.

12. Belchenko, L. A.; Akacharova, L. A. Adaptatsiya cheloveka i zhivotnykh k gipoksii raznogo proiskhozhdeniya [Adaptation of humans and animals to hypoxia of different origins (in Russian)]. Soros educational journal 2001, 7, pp. 33-39.

13. Demidov, D.I.; Chumachenko, S.S.; Andreev, V.P.; Nadolnik, L.I. Antioksidantnaya sistema mitokhondriy mozga krys pri vozdeystvii khronicheskogo psikhoemotsional'nogo stressa [Antioxidant system of rat brain mitochondria under the influence of chronic psychoemotional stress (in Russian)], Rep. abstr. Poster Session Abstracts, 2015, pp. 85 - 88.

14. Meshchaninov, V.N.; Shcherbakov, D. L. Vliyaniye neyromediatorov na perekisnoye okisleniye lipidov pri immobilizatsionnom stress-vozdeystvii u krys raznogo vozrasta [The effect of neurotransmitters on lipid peroxidation under immobilization stress in rats of different ages (in Russian)]. Kazan medical journal 2015, 96, 5, pp. 843-849.

15. Salei, A.P.; Retskiy, M.I. Rol oksida azota v formirovanii motivatsionnogo povedeniya [The role of nitric oxide in the formation of motivational behavior (in Russian)]. Voronezh State University Publishing House 2003, 1, pp. 75-80.

16. Calabrese, V.; Mancuso, C.; Calvani, M.; Rizzarelli, E. Nitric oxide in the central nervous system: neuroprotection versus neurotoxicity. Nature Reviews Neuroscience 2007, 8, 10, pp. 76675. doi:10.1038/nrn2214

17. Nelson, R.J.; Kriegsfeld, L.J.; Dawson, V.L.; Dawson, T.M. Effects of nitric oxide on neuroendocrine function and behavior. Frontiers in Neuroedocri 1997, 18, 4, pp. 463-91. doi:10.1006/frne.1997.0156

18. Tyurenkov, I.N.; Perfilova, V.N.; Prokofiev, I.I. Vliyaniye immobilizatsionno-bolevogo stressornogo vozdeystviya na zhivotakh s razlichnym fenotipom reagirovaniya $\mathrm{v}$ usloviyakh blokady NO-sintaz [Influence of immobilization-pain stressful action on abdomens with different reaction phenotypes under conditions of NO synthase blockade (in Russian)]. International Journal of Applied and Basic Research 2016, 6, 2, pp. 292-296. 
19. Dhabhar, F.S. Enhancing versus suppressive effects of stress on immune function: implications for immunoprotection and immunopathology. Neuroimmunomodulation 2009, 16, 5, pp. 300-17. doi: $10.1159 / 000216188$.

20. Padgett, D.A., Glaser, R. How Stress Influences the Immune Response. Trends in Immunology 2003, 24; pp. 444-48. doi:10.1016/S1471-4906(03)00173-X

21. Butenko, G.M.; Tereshina, O. P. Stress i immunitet [Stress and immunity (in Russian)]. International Medical Journal 2001, 3, pp. 91-94.

22. Zolotareva, T.A.; Zmievsky, A.V.; Nasibullin, B.A.; Yaroshenko N.A. Sovremennyye predstavleniya o mekhanizmakh stress-obuslovlennoy disfunktsii kletochnogo immunnogo otveta [Modern concepts of the mechanisms of stress-related dysfunction of the cellular immune response (in Russian)]. Word of Medicine and Biology 2011, 4, pp. 132-134.

23. Kuzmenko, L.G.; Kiseleva, N.M.; Simonova, A.V. Stareniye i timus [Aging and thymus (in Russian)]. The journal of scientific articles "Health \& education millennium" 2013, 15, 1-4, pp. 170-175.

24. Kapitonova, M.Yu.; Muraeva, N.A.; Chernov, D.A.; Khlebnikov, V.V.; Nesterova A.A. Vozrastnyye osobennosti sootnosheniya izmeneniy immunnykh parametrov $\mathrm{v}$ tsentral'nikh i perifericheskikh organakh immunogeneza pri khronicheskom stresse [Age-related features of the ratio of changes in immune parameters in the central and peripheral organs of immunogenesis in chronic stress (in Russian)]. Fundamental research 2006, 11, pp. 61-62.

25. Kirichek, L. T.; Shcherban, N. G. Metabolitnyye i metabolitotropnyye preparaty v sisteme stressprotektsii [Metabolic and Metabolithotropic Drugs in the Stress Protection System (in Russian)]. International Medical Journal 2012, 2, pp. 103-108.

26. Bochkareva, N.V.; Podsevatkin, V.G.; Kiryukhina, S.V.; Podsevatkina, S.V. Patogeneticheskiye mekhanizmy razvitiya khronicheskikh form stress-obuslovlennykh nevroticheskikh rasstroystv i vozmozhnosti ikh farmakologicheskoy korrektsii [Pathogenetic mechanisms of development of chronic forms of stress-related neurotic disorders and the possibility of their pharmacological correction (in Russian)]. Mental health 2015, 11, pp. 47-56.

27. Doklinichni doslidzhennya likarskykh zasobiv [Preclinical studies of drugs (in Ukrainian)]. Stefanov, O.V., Ed., Guidelines. Kyiv, 2001, p 527.

28. Guide to experimental (preclinical) studies of new pharmacological substances (in Russian). 2nd ed. Khabriev, R. U., Ed., OAO «Izdatel'stvo «Meditsina»: Moscow, 2005, p 832.

29. Kompendium - 2005: lekarstvennyye preparaty [Compendium - 2005: Medicines (in Russian)]. Kovalenko, V. N.; Viktorov, A.P., Ed., MORION: Kyiv, 2005; p 1920.

30. Willner, P. Validity, reliability and utility of the chronic mild stress model of depression: a 10-year review and evaluation. Psychopharmacology 1997, 134, 4, pp. 319-29. doi: 10.1007/s002130050456

31. Krupina, N.A.; Khlebnikova, N.N.; Orlova, I.N.; Popkova, E.V.; Rodina, V.I. et al. Effekty khronicheskogo myagkogo stressa u krys Vistar i Avgust: povedeniye i soderzhaniye monoaminov v striatume [The effects of chronic mild stress in Wistar and August rats: behavior and monoamine content in the striatum (in Russian)]. Pathogenesis 2012, 10, 2, pp. 50-58.

32. Amikishieva, A.V. Povedencheskoye fenotipirovaniye: sovremennyye metody i oborudovaniye [Behavioral phenotyping: modern methods and equipment (in Russian)]. VOGiS Bulletin 2009, 3, pp. 529-542.

33. Moy, S.S.; Nadler, J.; Peres, A.; Barbaro, R.P.; Johns, M. et al. Sociability and preference for social novelty in five inbred strains: an approach to assess autistic-like behavior in mice. Genes. Brain and Bechavior 2004, 3, pp. 287-302. doi: 10.1111/j.1601-1848.2004.00076.x

34. Buresh, J.; Bureshova, O.; Houston, D.P. Methods and Basic Experiments in Brain and Behavior Studies (from English). Moscow, 1991, p 399.

35. Cost, Ye. A. Directory of clinical laboratory research methods (in Russian). Medicine: Moscow, 1975; p. 383.

36. Orel, N.M. Biochemistry of membranes: a methodological guide (in Russian). BSU: Minsk, 2010; p 28.

37. Orekhovich, V.N. Sovremennyye metody v biokhimii [Modern methods in biochemistry (in Russian)]. M.: Moscow, 1977, p 392.

38. Glantz, S. Mediko-biologicheskaya statistika [Biomedical statistics (in Russian)]. Buzikashvili, N. Ye.; Samoilova, D.V., Ed., Praktika: Moscow, 1999, p 459. 
39. Kaluev, A.V. Stress, trevozhnost i povedeniye [Stress, anxiety and behavior (in Russian)]. Enigma: Kyiv, 1998; p 96.

40. Frolova, G.O. Otsinka zminy povedinkovykh kharakterystyk bilykh shchuriv v umovakh testu «diryave pole» pid diyeyu emotsiynoho stresu riznoho genezu [Evaluation of changes in the behavioral characteristics of white rats in the test "leaky field" under the influence of emotional stress of different genesis (in Ukrainian)]. Achievements of Biology and Medicine 2009, 1, 13, pp. 36-38.

41. Sheveryova, V.M. Vplyv khronichnoho emotsiynoho stresu na povedinku v testi «vidkryte pole» shchuriv z riznym rivnem rukhovoyi aktyvnosti [The effect of chronic emotional stress on behavior in the test "open field" rats with different levels of motor activity (in Ukrainian)]. Fiziologichnyi Zhurnal 2011, 57, 1, pp. 94-105.

42. Nemets, V.V.; Vinogradova, E.P. Stress i strategii povedeniya [Stress and behavior strategies (in Russian). National Psychological Journal 2017, 2, 26, pp. 59-72. doi:10.11621/npj.2017.0207

43. Khlebnikov, V.V.; Kapitonova, M.Yu.; Kuznetsov, S.L.; Nesterova, A.A.; Degtyar, Yu.V. et al. Immunogistokhimicheskaya kharakteristika selezenki pri deystvii razlichnykh vidov stressorov [Immunohistochemical characteristics of the spleen under the action of various types of stressors (in Russian)]. Morphology 2009, 5, pp. 61-66.

44. Anisimov, V.N. Molekulyarnyye i fiziologicheskiye mekhanizmy stareniya [Molecular and physiological mechanisms of aging (in Russian)]. Nauka: St. Petersburg, 2008, 1, p 481.

45. Huiyong, Yin; Libin, $\mathrm{Xu}$; Porter, Ned A. Free radical lipid peroxidation: Mechanism and analysis. Chem.rev. 2011, 111, 10, pp. 5944- 5972. doi: 10.1021/cr200084z

46. Gulyaeva, N.V. Perekisnoye okisleniye lipidov v mozgu pri adaptatsii $k$ stresu [Lipid peroxidation in the brain during adaptation to stress (in Russian)]. Author's abstract. diss. Doctor of Biological Sciences. Moscow, 1989; $\mathrm{p} 30$.

47. Kicheninm, K.; Decollogne, S.; Angignard, J.; Seman, M. Cardiovascular and pulmonary response to oral administration of ATP in rabbits. J. Appl. Physiol. 2000, 88, 6, pp. 196 -8. doi: 10.1152/jappl.2000.88.6.1962

48. Minaz, N.; Razdan, R. Therapeutic insight into molsidomine, a nitric oxide donor in streptozotocininduced diabetic nephropathy in rats. Indian. J. pharmacol. 2016, 48, 5, pp. 544-49. doi: 10.4103/02537613.190744

49. Samdanci, E.T.; Huz, M.; Ozhan, O.; Tanbek, K.; Pamukcu, E. et al. Cytoprotective effects of molsidomine against methotrexate-induced hepatotoxicity: an experimental rat study. Drug Des Devel Ther. 2019, 13, pp. 13-21. doi:10.2147/DDDT.S181550

50. Trevlopoulou, A.;, Touzlatzi, N.; Pitsikas, N. The nitric oxide donor sodium nitroprusside attenuates recognition memory deficits and social withdrawal produced by the NMDA receptor antagonist ketamine and induces anxiolytic-like behaviour in rats. Psychopharmacology (Berl). 2016, 233, 6, pp.1045-54. doi: 10.1007/s00213-015-4181-x.

51. Pshennikova, M. G.; Bondarenko, N. A.; Shimkovich, M. V. Oksid azota kak faktor geneticheski determinirovannoy ustoychivosti $\mathrm{k}$ stressornym povrezhdeniyam $\mathrm{i}$ adaptatsionnoy zashchity [.Nitric oxide as a factor of genetically determined resistance to stress damage and adaptive defense (in Russian)]. Bulletin of Experimental Biology and Medicine 2001, 11, pp. 510-513.

52. Markov Kh. М. Марков Х. M. Oksid azota i serdechno-sosudistaya sistema [Nitric oxide and the cardiovascular system (in Russian)]. Advances in Physiological Sciences 2001, 32, 3, pp. 49-65.

53. Malakhov, V.A.; Zavgorodnaya, A.N.; Lychko, V.S.; Dzhanelidze, T.T.; Volokh, F.O. Problema oksida azota v nevrologii: Monografiya [The problem of nitric oxide in neurology: Monograph (in Russian)]. SumDPU im. A. S. Makarenka: Sumy, 2009; p 242.

54. Manukhina, E.B.; Malyshev, I.Yu. Stress-limitiruyushchaya sistema oksida azota [Nitric oxide stress limiting system (in Russian)]. Russian Journal of Physiology 2000, 10, pp. 1283-1292.

55. Smirin, B.V.; Pokidyshev, D.A.; Malyshev, I. Yu. et al. Deponirovaniye oksida azota kak faktor adaptatsionnoy zashchity [Deposition of nitric oxide as an adaptive protection factor (in Russian)]. Russian Journal of Physiology 2000, 4, pp. 447-454.

56. Osipenko, A. Rol sistemy oksida azota v protsessakh adaptatsii organizma k fizicheskim nagruzkam [The role of the nitric oxide system in the adaptation of the body to physical activity (in Russian)]. Science in Olympic sports 2014, 1, pp. 23-30. 
57. Solovieva, A.G.; Kuznetsova, V.L.; Peretyagin, S.P.; Didenko, N.V.; Dudar, A.I.. Rol oksida azota v protsessakh svobodnoradikal'nogo okisleniya [The role of nitric oxide in free radical oxidation processes (in Russian)]. Bulletin Russian military medical academy 2016, 1, 53, pp. 228-233.

58. Kulchitsky, O. K.; Potapenko, R. I.; Novikova, S. N.; Stepanova, O. V.; Burchinskaya, M.K. Vozrastnyye osobennosti vliyaniya immobilizatsionnogo stressa na sostoyaniye sistemy monooksida azota $\mathrm{u}$ krys [Age characteristics of the effect of immobilization stress on the state of the nitrogen monoxide system in rats (in Russian)]. Problemi stareniya i dolgoletiya 2009, 18, 1, pp. 51-59.

59. Lutskiy, I.S. Vliniye khronicheskogo psikhoemotsional'nogo stressa na formirovaniye endotelial'noy disfunktsii, protsessy remodelirovaniya sosudov i snizheniye mozgovogo krovotoka [The influence of chronic psychoemotional stress on the formation of endothelial dysfunction, the processes of vascular remodeling and a decrease in cerebral blood flow (in Russian)]. Kuban Scientific Medical Bulletin 2015, 3, pp. 65-71.

60. Petrescu, P. Endothelin-1 plasma concentration in patients with essential hypertension, atherogenic dyslipidemia and coronary artery disease. Revista Română de Medicină de Laborator. 2010, 12, pp. 3554.

61. Dremina, N.N.; Shurygin, M.G.; Shurygina, I.A. Endoteliny v norme i patologi [Endothelin normal and pathological (in Russian)]. International Journal of Applied and Basic Research 2016, 10, 2, pp. 210214.

62. Pshennikova, M.G. Fenomen stressa: Emotsional'nyy stress i yego rol' v patologii [The phenomenon of stress: emotional stress and its role in pathology (in Russian)]. Pathological physiology and experimental therapy 2000, 2, pp. 20-26.

63. Duckles, S.P, Miller, V.M. Hormonal modulation of endothelial NO production. Pflugers Arch. 2010, 459, 6, pp. 841-851. doi:10.1007/s00424-010-0797-1.

64. Sorokina, I.V.; Bocharova, T.V. Dinamika izmeneniy v organakh immunnoy sistemy pri deystvii khronicheskogo svetovogo stressa [Dynamics of changes in the organs of the immune system under the action of chronic light stress (in Russian)]. Experimental And Clinical Medicine 2016, 2, 71, pp. 183188.

65. Polyakova, V.O.; Linkova, N.S.; Kvetnoy, I.M.; Khavinson, V.Kh. Funktsional'noye yedinstvo timusa i pineal'noy zhelezy $\mathrm{v}$ issledovanii mekhanizmov stareniya [Functional unity of the thymus and pineal gland in the study of aging mechanisms (in Russian)]. Bulletin of Experimental Biology and Medicine.

2011, 151, 5, pp. 565-568. 